\title{
Virulence of Beauveria bassiana Balsamo to red palm weevil, Rhynchophorus ferrugineus (Olivier) (Coleoptera: Curculionidae)
}

\author{
Rizwan Ahmed and Shoaib Freed ${ }^{*}$ (D)
}

\begin{abstract}
Background: The red palm weevil, Rhynchophorus ferrugineus (Olivier) (Coleoptera: Curculionidae), is a cosmopolitan pest of palms. Current management strategies largely depend on insecticides, and use of insect pathogenic fungi is needed in integrated pest management (IPM) programs.

Results: The effectiveness of Beauveria bassiana was determined against 3rd instar $R$. ferrugineus larvae by using the following concentrations, i.e., $3 \times 10^{8}, 2 \times 10^{8}, 1 \times 10^{8}, 1 \times 10^{7}$, and $1 \times 10^{6}$ spores $/ \mathrm{ml}$. The lowest $\mathrm{LC}_{50}$ value $\left(1.3 \times 10^{7}\right.$ spores $\left./ \mathrm{ml}\right)$ was recorded at the Khyber Pakhtunkhwa (KPK) population, followed by those populations from Punjab, Sindh, and Baluchistan, which had $\mathrm{LC}_{50}$ values of $1.5 \times 10^{7}, 5.3 \times 10^{7}$, and $1.02 \times 10^{8}$ spores $/ \mathrm{ml}$, respectively, on the 7th day post-treatment; the highest mortality rates were 90.0, 85.0, 77.5, and 75.0\% for the KPK, Punjab, Sindh, and Baluchistan populations, respectively, at the highest tested concentration of B. bassiana.

Conclusion: The findings of this study indicate the potential use of B. bassiana in IPM programs for $R$. ferrugineus that are more ecologically sound than those programs that are heavily reliant on insecticides.
\end{abstract}

Keywords: Biocontrol, Rhynchophorus ferrugineus, Date palm, Insect pathogenic fungi

\section{Background}

Phoenix dactylifera L., date palm, is an ancient crop that is cultivated worldwide mostly in tropical regions and can be found as an important part of both large- and small-scale farming (Khushk et al. 2009). The production of dates has been decreasing in Pakistan due to the effect of the red palm weevil, Rhynchophorus ferrugineus (Olivier) (Coleoptera: Curculionidae), which is a major pest of date palm all over the world (Abbas 2013). In the early stage of infestation, it is difficult to detect $R$. ferrugineus because it is concealed within the tree. In severe infestations, damaged trees can harbor multiple life stages at the same time (Faleiro 2006).

Synthetic insecticides are usually used to control insect pests that may cause resistance development, kill beneficial insects, pollute the atmosphere, and cause human

* Correspondence: sfareed@bzu.edu.pk

Department of Entomology, Faculty of Agricultural Sciences and Technology, Bahauddin Zakariya University, Multan, Punjab, Pakistan health hazards (Thomas and Read 2007). To mitigate these problems, integrated pest management needs to be adopted such as the use of safer insecticides in combination with biological control agents, for example, entomopathogenic fungi (EPF) (Wraight et al. 2001). The insect pathogenic fungi have significant importance due to their infectious ability to insects (Mustafa and Kaur 2009). Around the globe, Beauveria bassiana Balsamo, Metarhizium anisopliae Sorokin, Isaria fumosorosea Wize, and Beauveria brongniartii Petch are commonly used EPF (de Faria and Wraight 2007; Dembilio et al. 2010) . Fungi are used for the management of various insect orders, e.g., Coleoptera including $R$. ferrugineus (Hussain et al. 2015).

$B$. bassiana is eco-friendly, safe in use, and a wellknown biological control agent with a wide host range (Devi and Rao 2006). B. bassiana is a potential tool, and its efficacy differs among adult and larval instars of $R$. ferrugineus (Lo Verde et al. 2015). The present study was conducted to assess the potential of B. bassiana in

\section{Springer Open}

(๑) The Author(s). 2021 Open Access This article is licensed under a Creative Commons Attribution 4.0 International License, which permits use, sharing, adaptation, distribution and reproduction in any medium or format, as long as you give appropriate credit to the original author(s) and the source, provide a link to the Creative Commons licence, and indicate if changes were made. The images or other third party material in this article are included in the article's Creative Commons licence, unless indicated otherwise in a credit line to the material. If material is not included in the article's Creative Commons licence and your intended use is not permitted by statutory regulation or exceeds the permitted use, you will need to obtain permission directly from the copyright holder. To view a copy of this licence, visit http://creativecommons.org/licenses/by/4.0/. 
managing populations of $R$. ferrugineus under laboratory conditions from 4 provinces of Pakistan.

\section{Methods}

\section{Insect collection and rearing}

Rhynchophorus ferrugineus larvae and adults were collected from 4 provinces of Pakistan, i.e., Punjab $\left(30^{\circ} 11^{\prime} 52^{\prime \prime} \mathrm{N}: \quad 71^{\circ} 28^{\prime} 11^{\prime \prime} \mathrm{E}\right)$, Baluchistan $\left(28^{\circ} 22^{\prime} 37^{\prime \prime} \mathrm{N}\right.$ : $\left.68^{\circ} 21^{\prime} 2^{\prime \prime} \mathrm{E}\right)$, Sindh $\left(27^{\circ} 32^{\prime} \mathrm{N}: 68^{\circ} 46^{\prime} \mathrm{E}\right)$, and Khyber

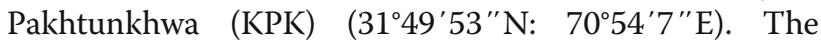
field-collected $R$. ferrugineus were transferred to sterile plastic cages $(30 \times 60 \times 60 \mathrm{~cm})$ covered with the muslin cloth. Adults of $R$. ferrugineus were reared on clean, fresh, and uninfected Saccharum officinarum stems (refreshed every 2 days). The larvae were reared on prepared diet following the method described by Hussain et al. (2015). The insects were reared under the laboratory conditions of $27 \pm 2^{\circ} \mathrm{C}, 70 \pm 5 \% \mathrm{RH}$, and $12 / 12 \mathrm{~h} \mathrm{~L} / \mathrm{D}$ photoperiod.

\section{Beauveria bassiana}

The local soil-extracted isolate of $B$. bassiana (Bb-01) was obtained from $\left(30^{\circ} 05^{\prime} 11.65^{\prime \prime} \mathrm{N} 71^{\circ} 39^{\prime} 15.65^{\prime \prime} \mathrm{E}\right)$ Multan, Punjab, Pakistan, and maintained in the Laboratory of the Insect Microbiology and Biotechnology and was used for the experiments.

\section{Fungal bioassay}

Third instar larvae of $R$. ferrugineus were used in the assays. Each larva was dipped for 10-15s in one of the following concentrations of $B$. bassiana, i.e., $3 \times 10^{8}, 2 \times$ $10^{8}, 1 \times 10^{8}, 1 \times 10^{7}$, and $1 \times 10^{6}$ spores $/ \mathrm{ml}$. All concentrations were prepared in an aqueous solution of $0.1 \%$ Tween 80 as defined by Alkhaibari et al. (2017). For each concentration and replicate, 80 larvae were exposed, at 4 replicates. A total of 480 larvae were tested in the bioassay including a control. For the control, only the aqueous solution containing Tween 80 was used. The treated larvae were placed in plastic Petri plates $(2.5-\mathrm{cm}$ diameter) with an artificial diet. The data on mortality was recorded on the 3rd, 5th, and 7th day post-treatment.

\section{Statistical analysis}

Fungal bioassay data were analyzed by the POLO Plus software (LeOra Software 2005) which yielded $\mathrm{LC}_{50}$ values, 95\% confidence limits (FL), slope $\pm \mathrm{SE}$, and chi-square values $\left(\chi^{2}\right)$. The means for mortality were separated among the treatments by using least significant difference (LSD) test $(P \leq 0.05)$. All analysis was performed by using Statistix 8.1 .

\section{Results}

\section{Virulence of $B$. bassiana against $R$. ferrugineus}

The virulence of B. bassiana on larvae of $R$. ferrugineus and the $\mathrm{LC}_{50}$ values were estimated for populations of the weevil collected from 4 provinces in Pakistan. The lowest $\mathrm{LC}_{50}$ value $\left(1.3 \times 10^{7}\right.$ spores $\left./ \mathrm{ml}\right)$ was recorded at the KPK population, followed by those populations from Punjab, Sindh, and Baluchistan, which had $\mathrm{LC}_{50}$ values of $1.5 \times 10^{7}, 5.3 \times 10^{7}$, and $1.02 \times 10^{8}$ spores $/ \mathrm{ml}$, respectively (Table 1 ).

\section{Virulence of $B$. bassiana against $R$. ferrugineus on different days post-treatment}

The highest percent mortality of the weevil larvae were $57.5,53.75,52.5$, and $50.0 \%$ on the 3rd day posttreatment, for the Punjab, KPK, Sindh, and Baluchistan populations, respectively (Table 2 ). On the 5 th day posttreatment, correspondent percentages were 70.0, 67.5, 65.0, and 53.75\% for the KPK, Punjab, Sindh, and Baluchistan populations, respectively (Table 3 ). On the 7th day post-treatment, respective mortality rates were 90.0, 85.0, 77.5, and $75.0 \%$ for the KPK, Punjab, Sindh, and Baluchistan populations, respectively (Table 4). These percent mortality rates occurred at the highest tested concentration of B. bassiana.

\section{Discussion}

The date growers mostly rely on the insecticides due to its rapid and spectacular results against $R$. ferrugineus. Development of an alternative strategy such as introduction of insect pathogenic fungi is necessary as a major component of IPM. EPF have proved to be an effective tool for the control of insect pests due to larvicidal

Table 1 Virulence of Beauveria bassiana against Rhynchophorus ferrugineus from Pakistan

\begin{tabular}{llllllll}
\hline Provinces & $\mathbf{L C}$ (50 $($ spores/ml) & $\mathbf{( 9 5 \% ~ F L ) ~}$ & Slope & $\boldsymbol{X}^{\mathbf{2}}$ & $\mathbf{d f}$ & $\boldsymbol{P}$ & $\mathbf{N}$ \\
\hline Punjab & $1.5 \times 10^{7}$ & $3.1 \times 10^{6}-4.0 \times 10^{7}$ & $0.55 \pm 0.11$ & 1.495 & 4 & 0.82753 \\
Sindh & $5.3 \times 10^{7}$ & $9.4 \times 10^{6}-1.8 \times 10^{8}$ & $0.27 \pm 0.05$ & 1.784 & 4 & 0.77541 \\
Baluchistan & $1.02 \times 10^{8}$ & $1.71 \times 10^{7}-5.06 \times 10^{8}$ & $0.27 \pm 0.05$ & 2.774 & 4 & 0.59633 \\
KPK & $1.3 \times 10^{7}$ & $2.6 \times 10^{6}-3.5 \times 10^{7}$ & $0.28 \pm 0.05$ & 5.151 & 4 & 0.27215 \\
\hline
\end{tabular}

$P$-values are based on Chi-square goodness of fit test. $P$ values $>0.05$ recommend goodness of fit of the model

$F L$ Fiducial limits, $N$ number of $R$. ferrugineus used in the bioassay, with the control 
Table 2 Percent mortalities of Rhynchophorus ferrugineus on the 3rd day after treatment with Beauveria bassiana

\begin{tabular}{lllll}
\hline $\begin{array}{l}\text { Concentrations } \\
\text { (spores/ml) }\end{array}$ & Baluchistan & Sindh & KPK & Punjab \\
\hline $\mathbf{1 \times 1 \mathbf { 0 } ^ { \mathbf { 6 } }}$ & $25.0 \mathrm{~cd}$ & $22.5 \mathrm{de}$ & $28.7 \mathrm{c}$ & $31.75 \mathrm{c}$ \\
$\mathbf{1 \times 1 \mathbf { 1 } ^ { \mathbf { 7 } }}$ & $32.5 \mathrm{bc}$ & $30.0 \mathrm{~cd}$ & $36.2 \mathrm{bc}$ & $40.0 \mathrm{bc}$ \\
$\mathbf{1 \times 1 \mathbf { 0 } ^ { \mathbf { 8 } }}$ & $37.5 \mathrm{abc}$ & $40.0 \mathrm{bc}$ & $42.5 \mathrm{ab}$ & $43.7 \mathrm{~b}$ \\
$\mathbf{2 \times 1 0 ^ { \mathbf { 8 } }}$ & $40.0 \mathrm{ab}$ & $42.5 \mathrm{ab}$ & $46.2 \mathrm{ab}$ & $45.5 \mathrm{~b}$ \\
$\mathbf{3 \times 1 0 ^ { 8 }}$ & $50.0 \mathrm{a}$ & $52.5 \mathrm{a}$ & $53.7 \mathrm{a}$ & $57.5 \mathrm{a}$ \\
Control & $13.75 \mathrm{~d}$ & $15.0 \mathrm{e}$ & $12.5 \mathrm{~d}$ & $18.7 \mathrm{~d}$ \\
F-value & 20.1 & 26.3 & 32 & 36.6 \\
P-value & 0 & 0 & 0 & 0 \\
LSD & 12.633 & 12.137 & 11.545 & 9.9983 \\
\hline
\end{tabular}

The values sharing same letters in columns are not significantly different $(P \leq 0.05)$

potential and less toxicity to non-target species (Freed et al. 2012).

B. bassiana is the most important EPF of Coleopterans (Cottrell and Shapiro-Ilan 2003) and showed promising results against the larvae of $R$. ferrugineus (Hajjar et al. 2015). In the present study, the pathogenicity of $B$. bassiana was evaluated against larvae of $R$. ferrugineus collected from 4 provinces of Pakistan. The highest percent mortality was found in the KPK population (90\%), followed by the Punjab (85\%), Sindh (77.5\%), and Baluchistan (75\%) populations at the highest concentration, 7th day post-treatment. These rates of mortality on day 7 suggest that the fungal spores successfully penetrated the cuticle of the larvae and were able to grow vegetatively inside the larvae, causing death due to a lack of nutrition (Inglis et al. 2001).

The outcomes of this study were consistent with Gindin et al. (2006) who examined the susceptibility of $R$. ferrugineus to B. bassiana at the concentration $2 \times 10^{7}$ spores $/ \mathrm{ml}$ that caused $100 \%$ larval mortality within $6-7$ days. Obtained results are also supported by the studies

Table 3 Percent mortalities of Rhynchophorus ferrugineus on the 5th day after treatment with Beauveria bassiana

\begin{tabular}{lllll}
\hline $\begin{array}{l}\text { Concentrations } \\
\text { (spores/ml) }\end{array}$ & Baluchistan & Sindh & KPK & Punjab \\
\hline $\mathbf{1 \times 1 0 ^ { \mathbf { 6 } }}$ & $32.5 \mathrm{~cd}$ & $35.0 \mathrm{~cd}$ & $35.0 \mathrm{~cd}$ & $31.2 \mathrm{~cd}$ \\
$\mathbf{1 \times 1 \mathbf { 0 } ^ { \mathbf { 7 } }}$ & $38.7 \mathrm{bc}$ & $41.2 \mathrm{bc}$ & $\mathbf{4 1 . 2 \mathrm { bc }}$ & $\mathbf{4 2 . 5 \mathrm { bc }}$ \\
$\mathbf{1 \times 1 0 ^ { \mathbf { 8 } }}$ & $45.0 \mathrm{ac}$ & $50.0 \mathrm{ac}$ & $47.5 \mathrm{bc}$ & $50.7 \mathrm{~b}$ \\
$\mathbf{2 \times 1 0 ^ { \mathbf { 8 } }}$ & $50.0 \mathrm{ab}$ & $55.0 \mathrm{ab}$ & $57.5 \mathrm{ab}$ & $55.0 \mathrm{ab}$ \\
$\mathbf{3 \times 1 0 ^ { \mathbf { 8 } }}$ & $53.7 \mathrm{a}$ & $65.0 \mathrm{a}$ & $70.0 \mathrm{a}$ & $67.5 \mathrm{a}$ \\
Control & $21.25 \mathrm{~d}$ & $18.7 \mathrm{~d}$ & $21.2 \mathrm{~d}$ & $21.2 \mathrm{~d}$ \\
F-value & 7.28 & 19.3 & 17.8 & 34.1 \\
P-value & 0.0007 & 0 & 0 & 0 \\
LSD & 20.040 & 16.646 & 18.254 & 12.840 \\
\hline
\end{tabular}

The values sharing same letters in columns are not significantly different $(P \leq 0.05)$
Table 4 Percent mortalities of Rhynchophorus ferrugineus on the 7th day after treatment with Beauveria bassiana

\begin{tabular}{lllll}
\hline $\begin{array}{l}\text { Concentrations } \\
\text { (spores/ml) }\end{array}$ & Baluchistan & Sindh & KPK & Punjab \\
\hline $\mathbf{1 \times 1 \mathbf { 1 } ^ { \mathbf { 6 } }}$ & $43.7 \mathrm{bc}$ & $45.0 \mathrm{c}$ & $50.0 \mathrm{~d}$ & $45.0 \mathrm{~d}$ \\
$\mathbf{1 \times 1 \mathbf { 1 } ^ { \mathbf { 7 } }}$ & $52.5 \mathrm{~b}$ & $52.5 \mathrm{bc}$ & $61.2 \mathrm{~cd}$ & $62.5 \mathrm{C}$ \\
$\mathbf{1 \times 1 \mathbf { 1 } ^ { \mathbf { 8 } }}$ & $57.5 \mathrm{ab}$ & $66.2 \mathrm{ab}$ & $70.5 \mathrm{bc}$ & $71.2 \mathrm{bc}$ \\
$\mathbf{2 \times 1 0 ^ { 8 }}$ & $65.0 \mathrm{ab}$ & $70.0 \mathrm{a}$ & $81.2 \mathrm{ab}$ & $80.0 \mathrm{ab}$ \\
$\mathbf{3 \times 1 \mathbf { 1 } ^ { \mathbf { 8 } }}$ & $75.0 \mathrm{a}$ & $77.5 \mathrm{a}$ & $90.0 \mathrm{a}$ & $85.0 \mathrm{a}$ \\
Control & $25.0 \mathrm{c}$ & $26.2 \mathrm{~d}$ & $27.5 \mathrm{e}$ & $26.2 \mathrm{e}$ \\
F-value & 12.7 & 28.9 & 45.1 & 70.4 \\
P-value & 0 & 0 & 0 & 0 \\
LSD & 21.961 & 15.781 & 15.099 & 11.992 \\
\hline
\end{tabular}

The values sharing same letters in columns are not significantly different $(P \leq 0.05)$

of Hou et al. (2018) who found that percent mortality of adult $R$. ferrugineus increased with increased conidial concentration applied. The highest concentration tested, $7.85 \times 10^{8}$ spores $/ \mathrm{ml}$, resulted in the highest mortality of the adult weevils. The findings were also supported by Yasin et al. (2019), who reported $>75 \%$ adult and $>88 \%$ larval mortality against $R$. ferrugineus by using B. bassiana. Collectively, the results of these studies suggest that mortality of various life stages of $R$. ferrugineus increased with increasing time after exposure and concentration of B. bassiana. Francardi et al. (2012) found that treatment of both larvae and adults of $R$. ferrugineus with $B$. bassiana resulted in $100 \%$ larval and $90 \%$ adult mortality under laboratory conditions. Moreover, El Husseini (2019) reported B. bassiana to be pathogenic against the 3rd instar larvae of $R$. ferrugineus causing 100\% mortality. However, Lo Verde et al. (2015) found higher efficacy of B. bassiana against weevil larvae than the adults. The high efficacy of $B$. bassiana against $R$. ferrugineus was demonstrated in field trials (Abbas 2013). In the present study, B. bassiana treatment resulted in $90 \%$ larval mortality, whereas in earlier studies, this treatment provided $45 \%$ mortality (Francardi et al. 2013). Findings of current research provided novel options to develop very effective biocontrol agents based on fungi. This research will facilitate productive date industry with the use of an efficient tactic for the management of $R$. ferrugineus.

\section{Conclusion}

In conclusion, the present study described $B$. bassiana pathogenicity in R. ferrugineus. B. bassiana with its novel mode of action properties is a good alternative to chemical control as it tremendously reduced the survival of $R$. ferrugineus. This research also opens novel options to develop mycoinsecticides that might provide date industry with an efficient technique for management of $R$. ferrugineus. 


\section{Abbreviations}

EPF: Entomopathogenic fungi; RH: Relative humidity; FL: Fiducial limits; IPM: Integrated pest management

\section{Acknowledgements}

Not applicable.

Studies involving plants must include a statement specifying the local, national, or international guidelines and legislation and the required or appropriate permissions and/or licences for the study (if applicable) Not applicable.

\section{Authors' contributions}

$\mathrm{RH}$ performed the experiment, analysis of data, and manuscript writing; SF contributed to technical assistance, analysis of data, supervision, and manuscript writing. The authors read and approved the final manuscript.

\section{Funding}

Not applicable.

\section{Availability of data and materials}

The data of the current research is available from the corresponding author on request.

\section{Declarations}

Ethics approval and consent to participate

Not applicable.

\section{Consent for publication}

Not applicable.

\section{Competing interests}

The authors declare that they have no competing interests.

Received: 24 January 2021 Accepted: 26 April 2021

Published online: 05 May 2021

\section{References}

Abbas MK (2013) Evaluation methods for red palm weevil control in Egypt during (1992-2010). In: Paper presented at the Palm Pest Mediterranean Conference (AFPP), France, Nice, 16-18 January 2013

Alkhaibari AM, Carolino AT, Bull JC, Samuels RI, Butt TM (2017) Differentia pathogenicity of Metarhizium blastospores and conidia against larvae of three mosquito species. J Med Entomol 54(3):696-704. https://doi.org/10.1 093/jme/tjw223

Cottrell TE, Shapiro-llan DI (2003) Susceptibility of a native and an exotic lady beetle (Coleoptera: Coccinellidae) to Beauveria bassiana. J Invertebr Pathol 84(2):137-144. https://doi.org/10.1016/j.jp.2003.09.003

De Faria MR, Wraight SP (2007) Mycoinsecticides and mycoacaricides: a comprehensive list with worldwide coverage and international classification of formulation types. Biol Control 43(3):237-256. https://doi.org/10.1016/j. biocontrol.2007.08.001

Dembilio Ó, Quesada-Moraga E, Santiago-Álvarez C, Jacas JA (2010) Potential of an indigenous strain of the entomopathogenic fungus Beauveria bassiana as a biological control agent against the red palm weevil, Rhynchophorus ferrugineus. J Invertebr Pathol 104(3):214-221. https://doi.org/10.1016/j.jip.201 0.04 .006

Devi KU, Rao CUM (2006) Allee effect in the infection dynamics of the entomopathogenic fungus Beauveria bassiana (Bals) Vuill. on the beetle, Mylabris pustulata. Mycopathol 161(6):385-394. https://doi.org/10.1007/s1104 6-006-0020-2

El Husseini MM (2019) Efficacy of the fungus Beauveria bassiana (Balsamo) Vuillemin on the red palm weevil Rhynchophorus ferrugineus Olivier (Coleoptera: Curculionidae) larvae and adults under laboratory conditions. Egypt J Biol Pest Control 29(1):58. https://doi.org/10.1186/s41938-019-0155-3

Faleiro JR (2006) A review of the issues and management of red palm weevil Rhyncophorus ferrugineus (Coleoptera: Rhynchophoridae) in coconut and date palm during the last one hundred years. Int J Trop Insect Sci 26(3):135-154
Francardi V, Benvenuti C, Barzanti GP, Roversi PF (2013) Auto contamination trap with entomopathogenic fungi: a possible strategy in the control of Rhynchophorus ferrugineus (Olivier) (Coleoptera: Curculionidae). Redia 96:57-67 Francardi V, Benvenuti C, Roversi PF, Rumine P, Barzanti G (2012) Entomopathogenicity of Beauveria bassiana (Bals.) Vuill. and Metarhizium anisopliae (Metsch.) Sorokin isolated from different sources in the control of Rhynchophorus ferrugineus (Olivier) (Coleoptera Curculionidae). Redia 95:49-55

Freed S, Saleem MA, Khan MB, Naeem M (2012) Prevalence and effectiveness of Metarhizium anisopliae against Spodoptera exigua (Lepidoptera: Noctuidae) in southern Punjab, Pakistan. Pak J Zool 44(3):753-758

Gindin G, Levski S, Glazer I, Soroker V (2006) Evaluation of the entomopathogenic fungi Metarhizium anisopliae and Beauveria bassiana against the red palm weevil Rhynchophorus ferrugineus. Phytoparasitica 34(4):370-379. https://doi. org/10.1007/BF02981024

Hajiar MJ, Ailan AM, Al-Ahmad MH (2015) New approach of Beauveria bassiana to control the red palm weevil (Coleoptera: Curculionidae) by trapping technique. J Econ Entomol 108(2):425-432. https://doi.org/10.1093/jee/tou055

Hou FJ, Addis SNK, Azmi WA (2018) Virulence evaluation of entomopathogenic fungi against the red palm weevil, $R$. ferrugineus (Coleoptera: Dryopthoridae). Malays Appl Biol J 47(5):25-30

Hussain A, Rizwan-ul-Haq M, Al-Ayedh H, Ahmed S, Al-Jabr AM (2015) Effect of Beauveria bassiana infection on the feeding performance and antioxidant defense of red palm weevil, Rhynchophorus ferrugineus. BioControl 60(6):849859. https://doi.org/10.1007/s10526-015-9682-3

Inglis GD, Goettel MS, Butt TM, Strasser H (2001) Use of Hyphomycetous Fungi for Managing Insect Pests. In: Butt TM, Jackson C, Magan N (eds.) - Fungi as Biocontrol Agents: Progress, Problems and Potential. CABI Int. Publishing, Wallingford, UK. pp. 23-69.

Khushk AM, Memon A, Aujla KM (2009) Marketing channels and margins of dates in Sindh, Pakistan. J Agri Res 47(3):293-308

Lo Verde G, Torta L, Mondello V, Caldarella CG, Burruano S, Caleca V (2015) Pathogenicity bioassays of isolates of Beauveria bassiana on Rhynchophorus ferrugineus. Pest Manag Sci 71(2):323-328. https://doi.org/10.1002/ps.3852

Mustafa U, Kaur G (2009) Extracellular enzyme production in Metarhizium anisopliae isolates. Folia Microbiol 54(6):499-504. https://doi.org/10.1007/ s12223-009-0071-0

Thomas MB, Read AF (2007) Can fungal biopesticides control malaria? Nat Rev Microbiol 5(5):377-383. https://doi.org/10.1038/nrmicro1638

Wraight SP, Jacksonz MA, De Kock SL (2001) Formulation of fungal biocontrol agents. In: Butt TM, Jackson C, Magan N (eds) Fungi as biocontrol agents: progress problems and potential. CAB Int, Wallingford, p 253. https://doi. org/10.1079/9780851993560.0253

Yasin M, Wakil W, Ghazanfar MU, Qayyum MA, Tahir M, Bedford GO (2019) Virulence of entomopathogenic fungi Beauveria bassiana and Metarhizium anisopliae against red palm weevil, Rhynchophorus ferrugineus (Olivier). Entomol Res 49(1):3-12. https://doi.org/10.1111/1748-5967.12260

\section{Publisher's Note}

Springer Nature remains neutral with regard to jurisdictional claims in published maps and institutional affiliations.

\section{Submit your manuscript to a SpringerOpen ${ }^{\circ}$ journal and benefit from:}

- Convenient online submission

- Rigorous peer review

- Open access: articles freely available online

High visibility within the field

- Retaining the copyright to your article

Submit your next manuscript at $\boldsymbol{\nabla}$ springeropen.com 